\title{
Modelling microbiological water quality in the Seine river drainage network: past, present and future situations
}

\author{
P. Servais ${ }^{1}$, G. Billen ${ }^{2}$, A. Goncalves ${ }^{3}$, and T. Garcia-Armisen ${ }^{1}$ \\ ${ }^{1}$ Ecologie des Systèmes Aquatiques, Université Libre de Bruxelles, Brussels, Belgium \\ ${ }^{2}$ UMR Sisyphe, Université Pierre \& Marie Curie, Paris, France \\ ${ }^{3}$ Syndicat Interdépartemental d'Assainissement de l'Agglomération Parisienne (SIAAP), Paris, France
}

Received: 10 April 2007 - Published in Hydrol. Earth Syst. Sci. Discuss.: 30 May 2007

Revised: 10 September 2007 - Accepted: 17 September 2007 - Published: 26 September 2007

\begin{abstract}
The Seine river watershed is characterized by a high population density and intense agricultural activities. Data show low microbiological water quality in the main rivers (Seine, Marne, Oise) of the watershed. Today, there is an increasing pressure from different social groups to restore microbiological water quality in order to both increase the safety of drinking water production and to restore the possible use of these rivers for bathing and rowing activities, as they were in the past. A model, appended to the hydro-ecological SENEQUE/Riverstrahler model describing the functioning of large river systems, was developed to describe the dynamics of faecal coliforms (FC), the most usual faecal contamination indicator. The model is able to calculate the distribution of FC concentrations in the whole drainage network resulting from land use and wastewater management in the watershed. The model was validated by comparing calculated FC concentrations with available field data for some well-documented situations in different river stretches of the Seine drainage network. Once validated, the model was used to test various predictive scenarios, as, for example, the impact of the modifications in wastewater treatment planned at the 2012 horizon in the Seine watershed in the scope of the implementation of the european water framework directive. The model was also used to investigate past situations. In particular, the variations of the microbiological water quality in the Parisian area due to population increase and modifications in wastewater management were estimated over the last century. It was shown that the present standards for bathing and other aquatic recreational activities are not met in the large tributaries upstream from Paris since the middle of the 1950's, and at least since the middle of the XIXth century in the main branch of the Seine river downstream from Paris. Efforts carried out for improving urban wastewa-
\end{abstract}

Correspondence to: P. Servais

(pservais@ulb.ac.be) ter treatment in terms or organic matter and nutrient loading resulted in a sensible reduction of microbiological contamination, but were not specific enough toward bacteriological contamination for achieving the objective of restoring levels compatible with bathing activities in the Parisian area.

\section{Introduction}

Polluted river waters can contain a large variety of pathogenic micro-organisms: viruses, bacteria and protozoa. The main origin of these micro-organisms is the direct and indirect release of men and warm-blood animals faeces into the aquatic environments. The sanitary risk for man linked to the presence of these pathogens depends on the use of the water (drinking, recreational activities, bathing, irrigation, shellfish harvesting) and on the pathogen concentration in water. During the nineteen-century, waterborne pathogens were responsible, in western European countries, of severe outbreaks of dysentery, typhoid fever and cholera responsible for thousands of deceases. In many developing countries, waterborne pathogens are still the first cause of morbidity.

In aquatic systems, the detection and enumeration of all pathogenic micro-organisms potentially present is very difficult due to the large diversity of pathogens, the low abundance of each species and the absence of standardized methods for their detection. Even if molecular tools able to detect several pathogens in the same water sample were recently developed (as e.g. DNA microarrays, Lemarchand et al., 2004), it is today impossible to base the routine monitoring of microbiological water quality on the direct detection of pathogens as this type of methods only provides information on the presence of a nucleic acid sequence and not on the viability of the pathogens. Thus, monitoring is still based on the concept of faecal bacterial indicators. These indicators

Published by Copernicus Publications on behalf of the European Geosciences Union. 
Table 1. Directive of the European Economic Community Council, December 12, 1975 on the microbiological quality of bathing waters (Directive 76/160).

\begin{tabular}{lcc}
\hline & Guide values & Mandatory values $^{\mathrm{a}}$ \\
\hline & $\mathrm{N}(100 \mathrm{ml})^{-1}$ & $\mathrm{~N}(100 \mathrm{ml})^{-1}$ \\
TC & 500 & 10000 \\
FC & 100 & 2000 \\
Salmonella & & 0 \\
Faecal streptococci $^{\mathrm{b}}$ & 100 & \\
\hline
\end{tabular}

${ }^{\text {a }}$ Based upon a 95-percentile evaluation.

b Concentration to be checked by the competent authorities when an inspection in the bathing area shows that the quality of the water has deteriorated.

Table 2. Directive of the European Community Council and Parliament, February 15, 2006 on the microbiological quality of bathing inland waters (Directive 2006/7/EC).

\begin{tabular}{lccc}
\hline & $\begin{array}{c}\text { Excellent } \\
\text { quality }\end{array}$ & $\begin{array}{c}\text { Good } \\
\text { quality }\end{array}$ & Sufficient \\
\hline & $\mathrm{N}(100 \mathrm{ml})^{-1}$ & $\mathrm{~N}(100 \mathrm{ml})^{-1}$ & $\mathrm{~N}(100 \mathrm{ml})^{-1}$ \\
Escherichia coli & $500^{\mathrm{a}}$ & $1000^{\mathrm{a}}$ & $900^{\mathrm{b}}$ \\
Intestinal enterococci & $200^{\mathrm{a}}$ & $400^{\mathrm{a}}$ & $330^{\mathrm{b}}$ \\
\hline
\end{tabular}

a Based upon a 95-percentile evaluation;

$\mathrm{b}$ Based upon a 90-percentile evaluation

are groups of bacteria that fulfil the following criteria: they should be universally present in large numbers in faeces of humans and warm-blooded animals, readily detected by simple methods; they should not grow in natural waters, but persist in water and be removed by water treatment in a similar way as waterborne pathogens (Havelaar et al., 2001). For more than a century, total coliforms (TC) and faecal (also called thermotolerant) coliforms (FC) were the main organisms used as bacterial indicators. Today, E. coli enumeration is often substituted to coliforms enumeration as there is evidence from epidemiological studies (Kay et al., 2004) that $E$. coli is a better bacterial indicator than coliforms to predict the sanitary risk associated with waters (Edberg et al., 2000). However, as FC is still the most widely used normative microbiological parameter, we have used it in this work as indicator of microbiological contamination.

All guidelines for assessing the water quality required for different water uses are based on the concentration of faecal bacterial indicators. For example, for bathing waters, the council of the European Economic Community has adopted in 1975 a directive, which defined the levels of TC, FC and streptococci acceptable in bathing waters (Table 1). The guideline compliance limit of bathing water for faecal coliforms was set to $100 \mathrm{FC}(100 \mathrm{ml})^{-1}$ and the maximum ad-

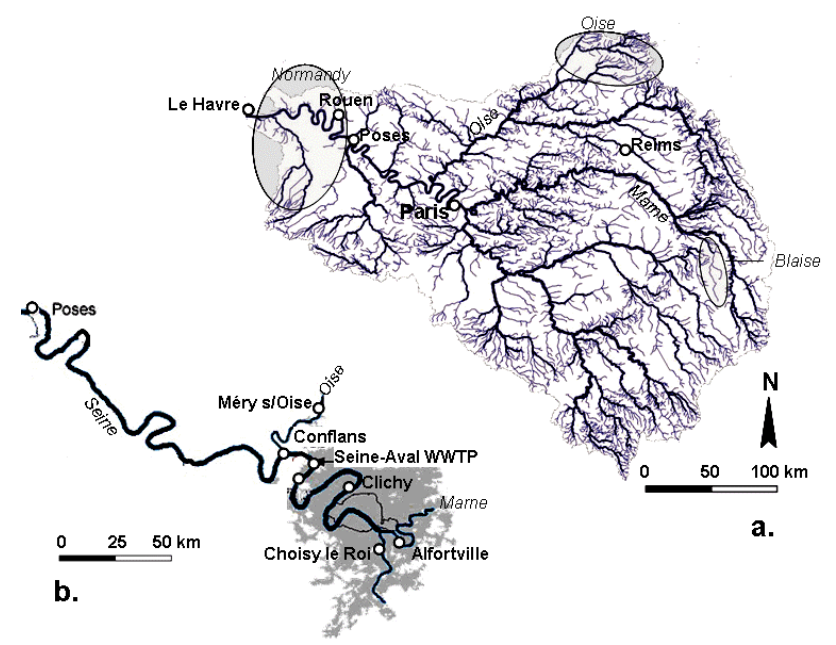

Fig. 1. (a) Map of the Seine river watershed. The Seine river and its two majors tributaries, Marne and Oise rivers are indicated. Areas of sampling in small rural streams in the Oise subwatershed (North of the watershed), in Normandy (West of the watershed) and in the Blaise basin (East of the watershed) are represented by grey zones; (b) Zoom on the Parisian area and the downstream branch of the Seine river.

missible level to $2000 \mathrm{FC}(100 \mathrm{ml})^{-1}$. In February 2006, a new directive on bathing water quality was adopted by the European Parliament and Council (Table 2), which will progressively replace the previous one in the different European countries. This new directive is based on the concentration of $E$. coli and intestinal enterococci, with different levels of compliance for inland and coastal waters. The levels fixed by this directive, based on recent epidemiological studies (Kay et al., 2004), set the maximum admissible level for $E$. coli to 900 E. coli $(100 \mathrm{ml})^{-1}$ in freshwaters. If we consider that E. coli represents on average 60 to $80 \%$ of $\mathrm{FC}$, as it is usually the case in freshwaters (Hamilton et al., 2005; GarciaArmisen et al., 2007), this means that the new regulation is considerably stricter than the previous one.

The present study concerns the microbiological quality of the rivers of the Seine drainage network. The Seine river watershed (Fig. 1) is characterized by a high population density, especially in the Parisian area, and intense agricultural activities. Water quality of the Seine hydrographical network is considerably affected by nutrient contamination and eutrophication (Garnier et al., 1995; Garnier and Billen, 2007; Billen et al., 2007) and present high levels of metallic (Meybeck et al., 2004, 2007; Thévenot et al., 2007) and organic micropollutants (Chevreuil et al., 1996) contamination. Research was conducted for several years to estimate the level of faecal contamination of the Seine drainage network, to quantify the sources of microbial contamination and to study the fate of faecal micro-organisms in the rivers. Data showed low microbiological water quality in the downstream parts of the main tributaries (Seine, Marne, Oise) (Fig. 1) (George 
et al., 2001; Servais et al., 2007). FC concentrations met in these rivers stretches usually exceed the maximum admissible level for bathing waters. Accordingly, bathing activities are no more allowed in the downstream stretches of the Seine, Marne and Oise rivers, where they occurred in the past, as attested by many famous impressionist's paintings as well as by more recent postcards. There is however an increasing pressure from different social groups to restore microbiological water quality for both increasing the safety of drinking water production and restoring the possible use of these rivers for aquatic recreational activities. A famous example of the interest for bathing in the Seine River, is the promise of French President Jacques Chirac, then mayor of Paris city, that he would swim in the Seine in the next future. Restoring a microbiological water quality compatible with bathing activities in the Parisian area was however a more difficult challenge that previously though, so that this goal is still not reached today.

In this paper we shall present and validate a model encompassing the problematic of faecal contamination at the scale of the whole drainage network of the Seine basin. By aid of this model, we shall test several scenarios in order to reconstruct the past state of microbiological contamination as well as to predict its possible future trends. We shall discuss the results in comparison with the recent normative regulations assessing the water quality required for allowing bathing activities.

\section{Material and methods}

\subsection{The Seine river watershed}

The Seine catchment $\left(75000 \mathrm{~km}^{2}\right)$ (Fig. 1) is characterised by a high population (average density of $195 \mathrm{inh} . \mathrm{km}^{-2}$ ), mainly concentrated in the urban area of Paris where densities exceed 500 inh. $\mathrm{km}^{-2}$ (Meybeck et al., 1998). Intense industrial activity occurs mainly in the Parisian area and along the estuarine stretch of the Seine River, associated with the harbours of Rouen and Le Havre. In the central part of the basin, an intensive agricultural activity exists, mostly oriented toward mass production of cereals and industrial crops. The drainage network totalises $22000 \mathrm{~km}$ of rivers of geomorphologic stream order (Strahler, 1957) ranging from 1 to 8. The average annual flow rate of the Seine River at the Poses Dam $(200 \mathrm{~km}$ downstream from Paris, the entrance of the estuarine sector) is $410 \mathrm{~m}^{3} \mathrm{~s}^{-1}$ with high flows in winter and low flows in summer.

In the Parisian area, two major tributaries (the Marne and Oise rivers) join the Seine, respectively at $\mathrm{pK}-4$ and 72 (Fig. 1). pK is a kilometric unit used by the Service de la Navigation de la Seine, which is set to zero at "Pont Marie" in downtown Paris and increases to the estuary; a negative pK thus locates stations upstream from Paris. The Seine river also receives the treated effluents of the 10 millions inhabi- tants of Paris and its suburbs, mainly through the effluents of the Seine Aval wastewater treatment plant $\left(6.5 \times 10^{6}\right.$ inhabitant equivalents capacity) located at Achères (pK 63) on the left bank of the Seine. Then, downstream the Seine and Oise rivers confluence ( $\mathrm{pK} 72$ ), the Seine river runs over more than $100 \mathrm{~km}$ without receiving any important tributary or effluents discharge until Poses (pK 202), where a navigation dam is an obstacle to tidal water movements upstream.

\subsection{Enumeration of faecal coliforms}

In the present study, faecal coliforms (FC) were enumerated after membrane filtration ( $0.45 \mu \mathrm{m}$-pore-size, $47-\mathrm{mm}$ diameter sterile cellulose nitrate filters, Sartorius) on lactose agar with Tergitol $(0.095 \%$ wt/vol final concentration) and triphenyl 2,3,5-tetrazolium chloride (TTC) $(0.024 \%$ o $\mathrm{wt} / \mathrm{vol}$ final concentration) according to the French standards (AFNOR, 2001). Plates were incubated at $44^{\circ} \mathrm{C}$ for $24 \mathrm{~h}$. Orange colonies producing a yellow halo under the membrane after incubation were considered FC colonies. This method was used both by the authors during their research activities presented in this paper and by the different authorities in charge of microbiological quality measurements (see Sects. 5.1 and 5.3). The detection limit of the method was $10 \mathrm{FC}(100 \mathrm{ml})^{-1}$ and the coefficient of variation was estimated at $30 \%$ based on series of replicates.

\section{Link between human activities in the watershed and microbiological water quality}

The microbiological quality of rivers is controlled by human activities in the watershed. In urban areas, faecal micro-organisms are mainly brought to aquatic environments through the discharge of domestic wastewater and some industrial wastewaters (treated in wastewater treatment plants (WWTPs) or not). In rural areas, faecal pollution can also be brought to rivers through non point sources (surface runoff and soil leaching); its origin can be the wild life animals and grazing livestock faeces and also cattle manure spread on cultivated fields.

\subsection{Microbiological pollution brought by wastewaters}

In order to quantify the contribution of treated wastewater to the faecal bacterial load, mean daily samples were collected in raw and treated waters of various wastewater treatment plants (WWTPs) located in the Seine watershed (Servais et al., 2007). The studied WWTPs have very different treatment capacities from more than 6 millions inhabitant-equivalents for the largest one to less than a thousand inhabitant-equivalents. They are also characterized by various types of water treatment (settling, activated sludge process with or without nitrification and/or denitrification, final UV disinfection). Details on sampling procedures and investigated WWTPs are presented in servais et al. (2007). 
(a)

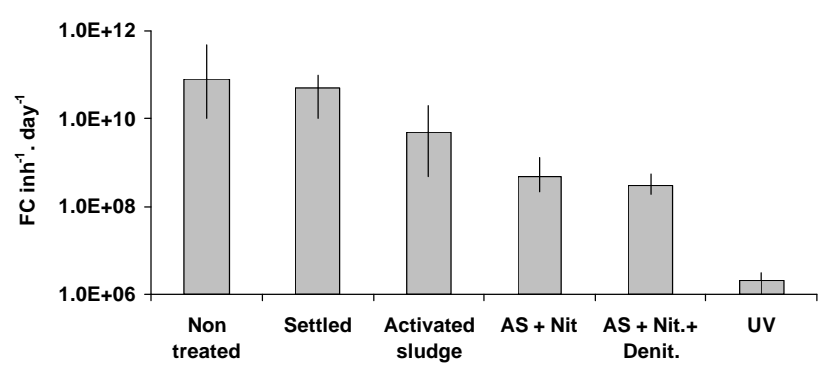

(b)

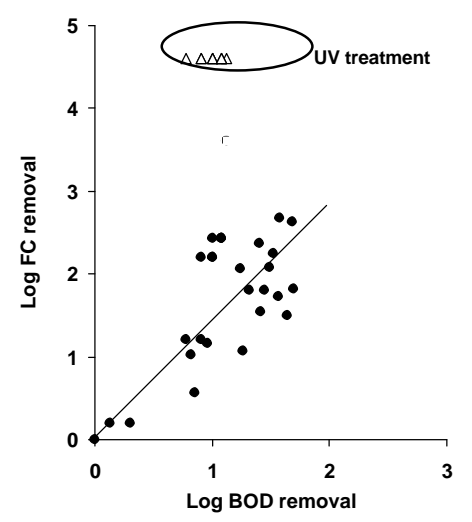

Fig. 2. (a) Specific loads of FC per inhabitant and per day for different types of wastewater treatment (number of samples considered to calculate the geometric means for type of treatment is indicated between brackets). Non-treated waters $(n=29)$; AS = activated sludge process followed by decantation $(n=6) ; \mathrm{AS}+$ nit $=$ activated sludge process with nitrification followed by decantation $(n=11)$, AS $+\mathrm{Nit}$ + Denit $=$ activated sludge process with nitrification and denitrification $(n=10)$, UV $=$ disinfection by UV irradiation added after secondary and tertiary treatment $(n=2)$. Vertical bars indicate the range between the minimum and the maximum values of specific loads calculated for each type of wastewater treatment. (b) Removal of FC expressed in Log units plotted against removal of Biological Oxygen Demand in Log units for a number of investigated wastewater purification plants.

FC measured in treated wastewater were expressed in terms of specific load per inhabitant per day, i.e. the daily numbers of FC discharged through wastewater by one inhabitant-equivalent which depends on the type of treatment applied to wastewater. Specific loads were calculated according to Servais et al. (1999), considering a daily load in Biological Oxygen Demand (BOD) of $54 \mathrm{~g}$ per inhabitant and per day as proposed by WHO (1982). For each WWTP, the daily wastewater volume per inhabitant $\left(\mathrm{m}^{3} \mathrm{inh}^{-1} \mathrm{day}^{-1}\right)$ was calculated by dividing the value of $54\left(\mathrm{~g} \mathrm{inh}^{-1} \mathrm{day}^{-1}\right)$ by the average BOD concentration in raw wastewater $\left(\mathrm{mgl}^{-1}\right)$. The specific load in treated wastewater was calculated by multiplying the FC concentration by the daily wastewater volume per inhabitant. The average specific loads ranged between $8 \times 10^{10} \mathrm{FC} \mathrm{inh}^{-1} \mathrm{day}^{-1}$ for untreated wastewaters to $2 \times 10^{6} \mathrm{FC} \mathrm{inh}^{-1}$ day $^{-1}$ for water first treated by activated sludge with nitrification and denitrification followed by a UV disinfection stage (Fig. 2a). The data show that, in the absence of a specific treatment stage designed to remove micro-organisms (as UV disinfection), the FC removal efficiency increased with the number of treatment stages but the maximum log removal is 2.5 (activated sludge with nitrification and denitrification). Presently, other technologies than UV disinfection exist to efficiently remove faecal microorganisms. For example, the efficiency of membrane bioreactors (Ottoson et al., 2006) and electrochemical disinfection (Diao et al., 2004) were demonstrated but these technologies were not tested in the present study.

Without specific disinfection step, removal of faecal bacteria in wastewater closely parallels the removal of BOD (Fig. 2b); when a UV disinfection treatment is applied, the removal of faecal micro-organisms increased to 4 to $5 \mathrm{log}$ units without modifying the BOD removal (Fig. 2b). As in the Seine watershed, only one WWTP is equipped with a disinfection stage, this means that the effluents released by the other WWTPs still contain high concentrations of FC (usually around $10^{5}$ to $\left.10^{6} \mathrm{FC}(100 \mathrm{ml})^{-1}\right)$. Data presented here clearly demonstrate that wastewater management is a key factor controlling the discharge of faecal micro-organisms and thus the level of contamination of the receiving surface waters.

3.2 Microbiological pollution brought by surface runoff and soil leaching

The contribution of non point sources was assessed by sampling small streams (order 1 or 2 streams according to the geomorphologic criteria defined by Strahler (1957)) located in rural areas. The small streams were sampled upstream from any wastewater outfall so that the microbiological contamination results only from water-soil interactions. These small streams were characterized on the basis of the land use of their watershed: forest areas, cultivated areas and grassland areas. Three zones of the Seine watershed were investigated (Fig. 1): the upper river Oise sub-basin, the blaise sub-basin and the normandy (Andelle, Eure and Risle rivers watersheds). Figure 3 presents the level of the geometric mean (for several sampling campaigns performed under various meteorological conditions) of FC concentrations due to surface runoff and soil leaching for the three types of land uses in the three investigated areas. Clearly, in the three regions, small streams draining pastures were significantly more contaminated (around $\left.1000 \mathrm{FC}(100 \mathrm{ml})^{-1}\right)$ than those draining forests or cultivated areas (around $\left.100 \mathrm{FC}(100 \mathrm{ml})^{-1}\right)$, while no significant difference exists between mean FC concentrations in forests and cultivated areas, in agreement with previous observations by George et al. (2004) and Collins and Rutherford (2004). 


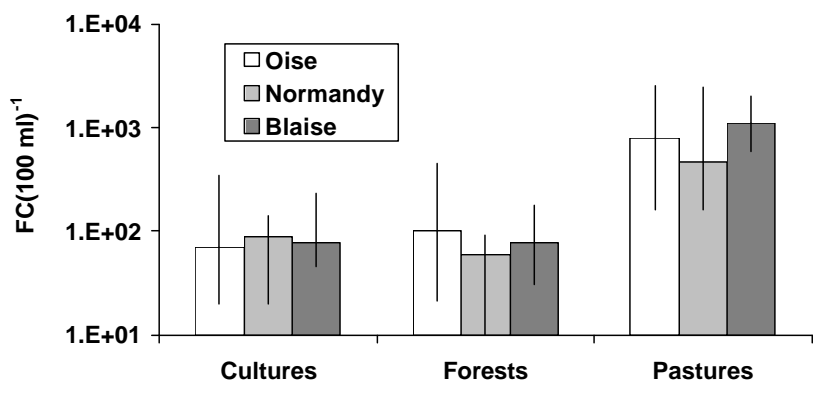

Fig. 3. FC concentrations in small streams flowing through forest $(\mathrm{F})$, cultivated $(\mathrm{C})$ or pastured $(\mathrm{P})$ areas in the Oise sub-watershed, in Normandy and in the Blaise watershed. Data were expressed as geometric mean values for each category calculated on 8, 2 and 4 sampling campaigns in the Oise subwatershed, Normandy and in the Blaise watershed, respectively. The number of streams sampled in each category was $4(\mathrm{~F}), 4(\mathrm{C})$, and $4(\mathrm{P})$ in the Oise subwatershed, $4(\mathrm{~F}), 2(\mathrm{C})$, and $5(\mathrm{P})$ in Normandy and $2(\mathrm{~F})$ and $10(\mathrm{P})$ in the Blaise watershed. Vertical bars indicate the range between the minimum and the maximum values measured in each category of small streams. Part of the data used to calculate the geometric means is from George et al. (2004).

Based on such data, calculations performed at the scale of the large urbanized Seine watershed have shown that the input of faecal micro-organisms by non-point sources was much lower (around one hundred times) than the inputs by point sources (Servais et al., 2007; Garcia-Armisen and Servais, 2007). However, diffuse sources can have a major local impact on the microbiological quality of small rivers.

\section{Microbiological quality model}

The knowledge gained on the source and fate of faecal bacteria in the Seine drainage network can be used as input data to a model describing the dynamics of FC within the whole Seine drainage network. This model consists of a module appended to the hydro-ecological SENEQUE/Riverstrahler model describing the functioning of large river systems (Ruelland et al., 2007). The Riverstrahler model (Billen et al., 1994; Garnier et al., 2002) combines a simplified characterisation of the drainage network of large regional basins and their hydrology (Hydrostrahler model), to a refined representation of in-stream microbiological processes (RIVE model), in order to calculate the water quality and ecological functioning resulting from both climatic and hydrological constraints and anthropogenic activities (agriculture, domestic and industrial) in the watershed (Fig. 4). In the SENEQUE software, this model is embedded within a GIS interface, allowing the use of fully distributed geo-data bases (Ruelland et al., 2007). The addition of a module describing the dynamics of FC to the SENEQUE model (FCSENEQUE) allows including FC concentration as an additional state variable which can be calculated by the model in

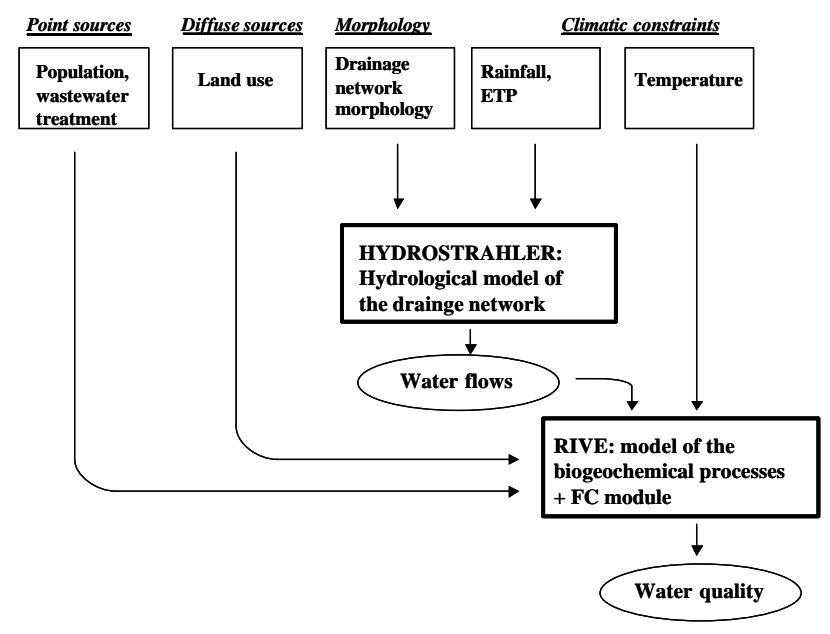

Fig. 4. Schematic representation of the structure of SENEQUE/Riverstrahler model including the module describing the dynamics of FC. The sources of FC considered in the FC module are the point sources and the diffuse sources. The release of FC by WWTPs effluents are calculated by multiplying the capacity of each WWTP by the corresponding specific load of FC per inhabitant and per day (Fig. 2a) depending on the type of treatment applied. The diffuse sources are calculated on the basis of land use (forests, cultivated, grazed and urban areas) in all elementary sub-basins of the watershed and the release of FC due to surface runoff and soil leaching on each type of land use estimated in this study (Fig. 3). The processes affecting the fate of faecal bacteria in the FC module are the decay (first order rate kinetics with the first order rate constant depending on temperature) and the sedimentation (characterised by the sinking rate).

the whole drainage network for which the suitable database has been assembled.

The water flows in the hydrographical network are calculated by the model considering rainfall and evapotranspiration. The discharge of any stream is the sum of two components, the surface runoff and the base flow from groundwater. These two components are calculated by 10 days periods. For recent years, the real climatic constraints (rainfall and temperature) obtained from meteorological databases are considered by the model to calculate rivers discharges. As the variation of the hydrology in the basin is large with mean annual specific discharge in the range $41 \mathrm{~km}^{-2} \mathrm{~s}^{-1}$ to $141 \mathrm{~km}^{-2} \mathrm{~s}^{-1}$, a hydrology corresponding to the long-term mean hydrological conditions $\left(7.71 \mathrm{~km}^{-2} \mathrm{~s}^{-1}\right)$ was considered for the retrospective scenarios presented in this paper.

In the model, the non point sources (surface runoff and soil leaching) of FC are calculated on the basis of land use in all elementary sub-basins of the watershed. SENEQUE affects a specified (experimentally determined, see part 3.2) FC concentration to the calculated surface runoff discharge from each land use class. Forests $\left(100 \mathrm{FC}(100)^{-1}\right)$, cultivated $\left(100 \mathrm{FC}(100)^{-1}\right)$, grazed $\left(1000 \mathrm{FC}(100)^{-1}\right)$ and urban $\left(5000 \mathrm{FC}(100)^{-1}\right)$ areas are distinguished. A base level 


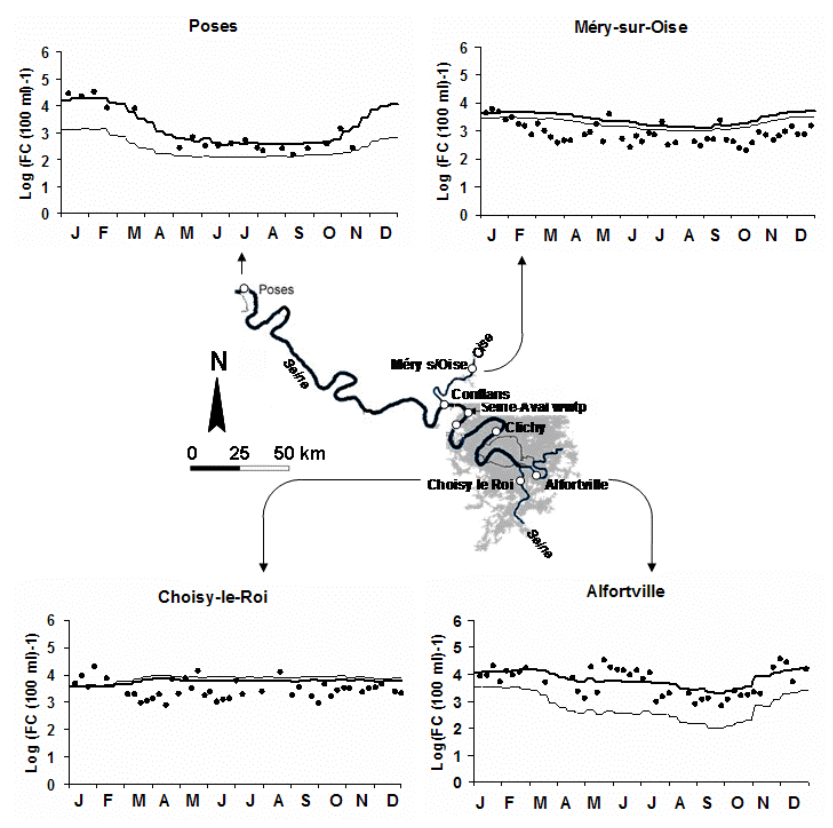

Fig. 5. Seasonal variations of FC concentrations calculated by the FC-SENEQUE model for the year 2003 (bold line) and for the year 2012 (prospective scenario)(fine line) at the entrance of Parisian area on the Seine river (Choisy-le-Roi), the Marne river (Alforville), the Oise river (Méry-sur-Oise) and at the entrance of the Seine estuary (Poses). Field data (black dots) for the year 2003 are also plotted (SIAAP, SEDIF-CGE and SNS, personal communication)

of FC due to soil leaching $\left(20 \mathrm{FC}(100)^{-1}\right)$ is also affected to base flow. The point sources of FC associated to wastewater inputs are calculated on the basis of a file communicated by the "Seine Normandy Water Agency" giving the capacity and the type of treatment for each WWTP in the Seine watershed. The capacity of each WWTP is multiplied by the corresponding specific load of FC per inhabitant and per day (Fig. 2) depending on the type of treatment applied to obtain the flux of FC released to rivers.

The disappearance of culturable faecal bacteria in aquatic environments results from the combined actions of various biological and physico-chemical processes (grazing by protozoa; virus-induced cell lysis and autolysis; stress due to nutrients depletion, sunlight intensity, and temperature decrease inducing mortality or loss of culturability; deposition on bottom sediments). In agreement with the results of batch experiments conducted by adding FC to sterile Seine river water, we neglect in the model the possibility of any significant growth of faecal bacteria in river waters. The decay of FC due to biological and physico-chemical processes is described by a first order kinetics. This type of kinetics has been already shown to correctly describe the disappearance of faecal bacteria in aquatic systems (Tian et al., 2002; Kashefipour et al., 2002; Collins and Rutherford, 2004; Menon et al., 2003). A first order disappearance rate

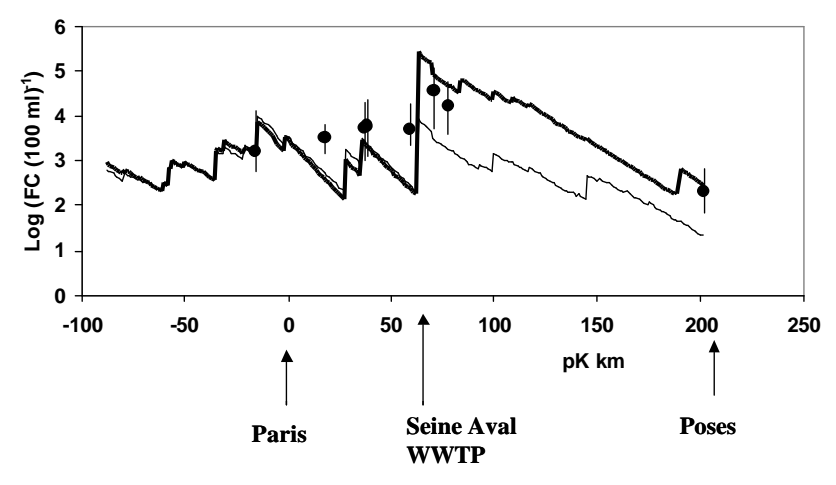

Fig. 6. Longitudinal variations in summer conditions of FC concentrations calculated by the FC-SENEQUE model for the year 2003 (bold line) and for the year 2012 (prospective scenario)(fine line) in the Seine river between the confluence of the Seine with the Yonne river (pK -88) and the entrance of the estuary (pK 202). Average (from 7 to 10 field measurements at each sampling station) field data (black dots) for the summer 2003 period are also plotted (SIAAP and SNS, pers. com.). Vertical bars indicate the range between the maximum and the minimum values measured at each sampling station during summer 2003. pK is a kilometric unit that is set at zero at "Pont Marie" in Paris downtown and increases from upstream to downstream (negative values are thus for stations upstream Paris).

of $45 \times 10^{-3} \mathrm{~h}^{-1}$ at $20^{\circ} \mathrm{C}$ was considered for all rivers of the drainage network; this first order decay rate varies with temperature following a sigmoid relationship. For calculating the settling of FC, an average sinking rate of $0.02 \mathrm{~m} \mathrm{~h}^{-1}$ was used. Experiments conducted to determine the first order decay rate and the sinking rate of FC are extensively described in Servais et al. (2007)

\section{Modelling microbiological quality in Seine drainage network}

\subsection{Present situation}

Model calculations using the FC-SENEQUE model were compared to field FC data in order to validate the model for some well-documented situations in different stretches of various rivers in the Seine drainage network (Figs. 5 and 6). The year 2003, characterized by low discharge and high summer temperature, was chosen for this validation exercise. Figure 5 shows temporal fluctuations of FC concentration (values calculated by the FC-SENEQUE model and field data) at four stations in the watershed. These stations are located at the entrance of the Parisian area on the Seine river (Choisy-le-Roi), the Marne river (Alforville) and the Oise river (Méry-sur-Oise) and on the Seine river at the upstream limit of the estuary (Poses) (Fig. 1b). Figure 6 shows the longitudinal distribution of FC in the Seine river between the confluence of the Seine with the yonne river $(\mathrm{pk}-88)$ and the entrance of the estuary (pk 202) for the summer 2003 
situation. Field data are averages of FC numbers measured weekly at each station during the summer 2003. Model calculations are averages for the summer 2003 situation (averages at all the stations along the profile of the 9 decades between beginning of July to end of September 2003).

In both figures a correct agreement between model calculations and field data is observed. Note that the model considers average and constant specific point and diffuse loads of FC, although as shown in Figs. 2a and 3 these loads display some variability which causes scatter in the field data. The model thus smoothes the observed variability displayed by the field measurements. The agreement between model calculations and field data concerns the average FC concentrations at the different stations but also the seasonal variations when they are observed. At Poses and to a lesser extend at Alfortville, field data showed lower FC concentrations during the low flow periods; this trend is also observed for the values calculated by the model. The agreement between field and calculated data presented here, as well as those previously shown in other stretches of the drainage network (Servais et al., 2007), indicates the ability of this model to correctly describe the distribution of FC in the rivers of the Seine watershed.

In 2003, at the entrance of the Parisian area, the microbial pollution was higher in the Marne river (average of FC concentration measurements: $\left.4900 \mathrm{FC}(100 \mathrm{ml})^{-1}\right)$ than in the Seine river (average of FC concentration measurements: $\left.2750 \mathrm{FC}(100 \mathrm{ml})^{-1}\right)$ and in the Oise river (average of FC concentration measurements: $\left.780 \mathrm{FC}(100 \mathrm{ml})^{-1}\right)$ (Fig. 5).

The longitudinal profile in the Seine river from the SeineYonne confluence to the entrance of the estuary at Poses (pk 202) calculated by the model for the summer 2003 situation (Fig. 6) shows a series of peaks of FC numbers, each corresponding to the impact of WWTP effluents. Between peaks, FC decrease linearly in logarithmic scale, reflecting the first order decay of faecal bacteria. The major impact on microbiological water quality in the profile is due to the outfall of the large Seine Aval WWTP at Achères (pk 63). The effluents of this plant obviously severely damage the microbiological quality of the receiving river as FC numbers just downstream the outfall reached around $1 \times 10^{6} \mathrm{FC}$ $(100 \mathrm{ml})^{-1}$. Downstream from Seine Aval WWTP outfall, FC concentration decreased in the Seine river, partly because of the dilution of the highly contaminated Seine water by the less contaminated Oise river (confluence $9 \mathrm{~km}$ downstream from the Seine Aval WWTP outfall). With the travel of water downstream to the estuary, a great reduction of FC concentration was observed along the $140 \mathrm{~km}$ between the Seine Aval WWTP outfall and the Poses dam. Data calculated along the profile were compared to the european standards regarding microbiological water quality of bathing waters: along the whole profile, FC concentrations greatly exceed the guideline standard for bathing waters, however, they are close to the mandatory standard in the Seine upstream from the Parisian agglomeration and at the entrance of the estuary at Poses.
At Poses station, FC concentration presents a clear temporal fluctuation with lower values during the low flow period (Fig. 5). The microbial contamination observed there is mainly coming from the Parisian area and more precisely from the Seine Aval treated effluents as shown by the longitudinal profile (Fig. 6). The decrease after the maximum of FC concentration is more important for the low discharge situations than for the high discharge situations; this can be explained by a higher residence time of the water bodies between Paris and Poses allowing for the mortality processes to occur for a longer period of time in low discharge situations.

The concentrations of FC measured in this study in the Seine and its tributaries upstream Paris (Marne, Oise) were within the range usually found in large rivers of watershed with quite high population densities in their watershed. FC counts in the range $10^{3}$ to $10^{4} \mathrm{FC}(100 \mathrm{ml})^{-1}$ were, for example, reported in the Meuse river in Belgium and The Netherlands (van Breemen et al., 1998; MRW-DGRNE, 2007) and in the Schelde river (Belgium) (MRW-DGRNE, 2007). The longitudinal profile of FC concentration in the Seine river in the Parisian area clearly showed the major negative impact that outfalls of treated wastewaters can have on the microbiological water quality of the receiving river. Similar degradations of river microbiological quality due to the discharge of treated urban wastewater effluents were reported in the literature. For example, a large increase of faecal bacterial indicators concentration was observed in the Thames river downstream London (Tryland et al., 2002) where $E$. coli concentration can reach up to $10^{5}$ E. coli $(100 \mathrm{ml})^{-1}$. A moderate increase in coliforms counts was observed in the Danube river downstream Vienna (Hoch et al., 1996). The importance of such quality decrease is directly related to the ratio of the effluents and the river flow rates and to the faecal bacteria concentration in the treated effluent depending on the type of treatment. The worst situations in terms of microbiological contamination are observed in rivers downstream important release of untreated wastewaters of large cities. This occurs quite frequently in developing countries where some big towns are not equipped with WWTPs. As an example, Duc et al. (2007) reported the major negative impact of untreated wastewaters release of Hanoi (Vietnam) on the microbiological quality of the Nhue river.

The FC-SENEQUE model can also provide a representation of the distribution of FC in the whole Seine drainage network. Figure 7 presents this distribution for the summer 2003 situation. High microbiological quality waters (blue and green on the map), corresponding to FC levels below the guideline standard for bathing waters, are found in some headwater streams. These streams are characterized in summer by an important contribution of low contaminated groundwaters and no point source wastewater contamination. Groundwaters are usually less contaminated than runoff waters due to the efficient removal of faecal micro-organisms during water percolation in soil (Matthess et al., 1988). Most of the headwater streams in the watershed have FC numbers 


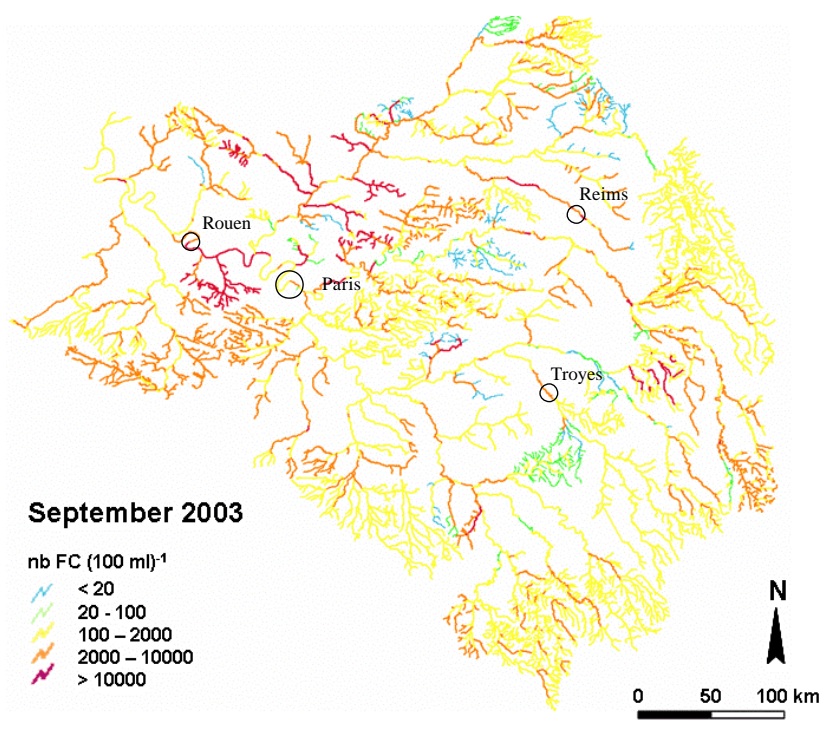

Fig. 7. Map of the distribution of FC concentrations in the rivers of the Seine drainage network for the summer 2003 situation, as calculated by FC-SENEQUE model.

between 100 and $2000(100 \mathrm{ml})^{-1}$. This is not surprising as this range of concentrations can result from surface runoff in rural areas as shown in Sect. 3.2 of this paper. A lot of stretches of intermediate stream order (2 to 5) rivers belong to the yellow category on the map (Fig. 7) meaning that the microbiological quality allows bathing activities during summer in dry weather conditions. Low microbiological water quality (orange and red on the map) with FC numbers higher than $2000(100 \mathrm{ml})^{-1}$ are usually observed in rivers impacted by wastewater release. The case of the Seine downstream the Parisian has already been discussed here above. The map shows that some small streams are also of low microbiological quality, especially around Paris; this is due to high population density in areas in which no large streams are available to receive the treated wastewaters.

\subsection{Future situations investigated by prospective modelling}

The FC-SENEQUE model can be a useful tool to investigate the impact of future modifications in wastewater management on the microbiological water quality, as for example, the improvement in wastewater treatment planned at the 2012 horizon in the Seine watershed in the scope of the implementation of the European Water Framework directive. By this time, all WWTP above 10000 inhabitants equivalent should be equipped with treatment lines including at least nitrification and dephosphatation steps. The most important changes planned concerns the Seine Aval WWTP: (i) the wastewater volume treated in this plant will be significantly reduced as a part of the wastewater presently treated there will be routed to both the Seine amont WWTP (pk -9) and a new plant at Les Grésillons (pk 100); (ii) the treatment in Seine Aval
WWTP will be significantly improved compared to the 2003 situation with the addition of nitrification and denitrification stages as well as a final flocculation-settling process to remove phosphorus.

Figures 5 and 6 allow easy comparison of the present level of faecal contamination and the improvement that will result from the implementation of these measures. Upstream from Paris, a significant improvement of microbiological water quality is predicted in the Marne river with regards to the present situation. In the Oise river, a very small improvement of quality is predicted by the model while the situation will remain unchanged in the Seine at the entrance of the Parisian area. The significant difference (around a $1 \log$ factor in low flow conditions) in the Marne river just upstream its confluence with the Seine river is related to the implementation of a UV disinfection treatment at the Marne Aval WWTP located at Noisy-le-Grand, some kilometres upstream the Alfortville station. The longitudinal profile (Fig. 6) shows that a spectacular increase in water quality is predicted by the model downstream Achères and up to the entrance of the estuary. This is due to the considerable improvement of the treatment at the Seine Aval WWTP in 2012, decreasing the input of FC by a factor around 30 .

\subsection{Past situations investigated by retrospective modelling}

The FC-SENEQUE model was also used to investigate past situations. The variations of the microbiological water quality in the Seine river in the Parisian area due to population increase and modification in wastewater management were estimated over the last century. Retrospective modelling requires that the past sources of faecal contamination of rivers be estimated. As point sources through wastewater release are today largely dominant (Servais et al., 2007), one can assume that it was also the case during the whole nineteenth century. During this period, only a fraction of wastewater was treated, mostly by using urban wastewater for fertilizing agricultural fields. Based on historical data of population and wastewater treatment capacity (Billen et al., 2001; Barles, 2007), Billen et al. (2007) have reconstituted the past load of organic matter and nutrient from point sources over the last 2 centuries, treating separately the upstream sub-basins (upstream the entrance of the Parisian area) (Fig. 8a), and the Parisian area (Fig. 9a). In order to calculate the corresponding input of FC through wastewater release, we have assumed that an approximate constant ratio exists between the release of biodegradable organic matter (expressed in terms of Biological Oxygen Demand - BOD) and the release of FC. This ratio $\left(1.2 \times 10^{9} \mathrm{FC}(\mathrm{gBOD})^{-1}\right)$ was established on the basis of parallel measurements of BOD and FC concentration in wastewaters collected in various WWTPS in the Seine basin (George et al., 2002; Servais et al., 2007) (see Fig. 2b). Accordingly, FC were calculated by multiplying this ratio by the bod release estimated on the basis of the historical reconstitution presented in Figs. 8a and 9a. 
(a)

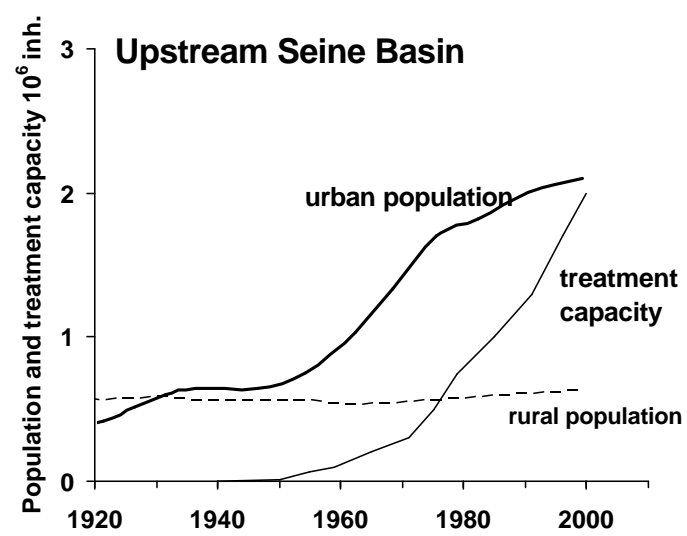

(b)

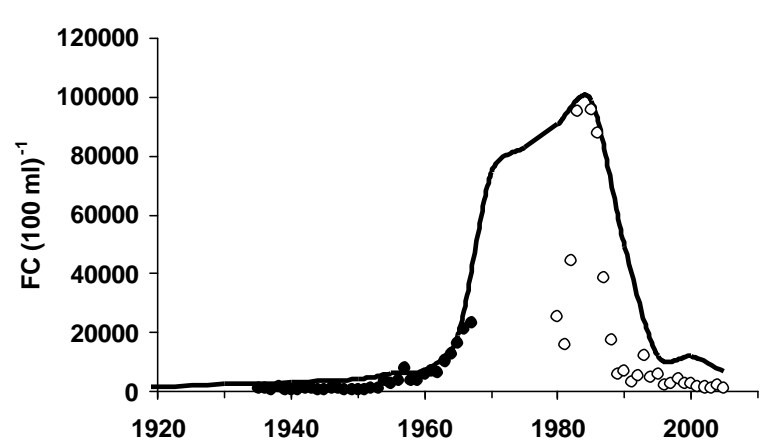

Fig. 8. (a) Historical reconstitution of urban and rural populations and wastewater treatment capacity for the period 1920-2000 in the upstream Seine river basin (limited at the entrance of the Parisian area) (Billen et al., 2007); (b) Calculation of the FC concentrations at Choisy-le-Roi by the FC-SENEQUE model. Experimental data are annual averages; for the period 1935-1965, they are from Mangerel (1969) and for the period 1980-2000 from the routine control of the raw water at the drinking water treatment of Choisy-le-Roi (SEDIF-CGE, personal communication).

The concentrations of FC in the Seine river at the Choisyle-Roi station (at the entrance of the Parisian area) between 1920 and 2005 were calculated by retrospective modelling using the FC-SENEQUE model (Fig. 8b). The results are compared with the data of two surveys of FC concentration at the Choisy-le-Roi station. For the first one, which concerns the period 1935-1965 (Mangerel, 1969), E. coli numbers were in fact experimentally determined and converted in FC numbers using an average ratio $E$. coli/FC of 0.77 determined on river water samples from the Seine watershed by GarciaArmisen et al. (2007). The second survey (years 1980-2006) was performed in the raw water (Seine river water) from the Choisy-le-Roi drinking water treatment plant (SEDIF-CGE, personal communication). Figure $8 \mathrm{~b}$ first shows that, for the period for which field data are available, calculations of FC concentrations by the FC-SENEQUE model are in quite good agreement with field data. A slow increase of the faecal pollution is observed in the Seine upstream Paris between 1920 (a)

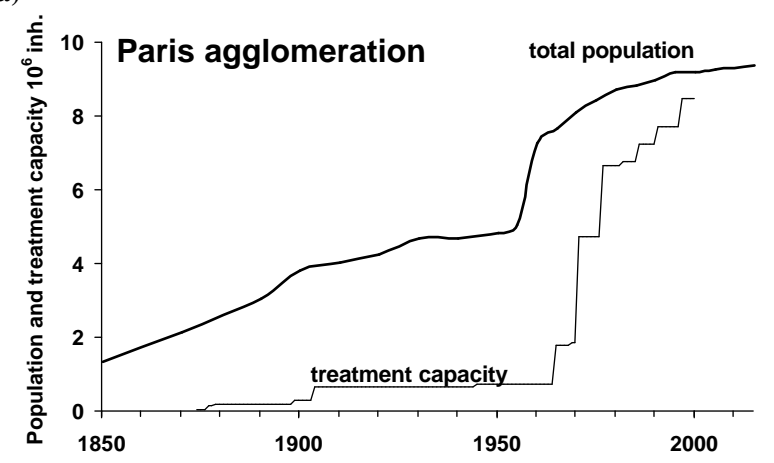

(b)

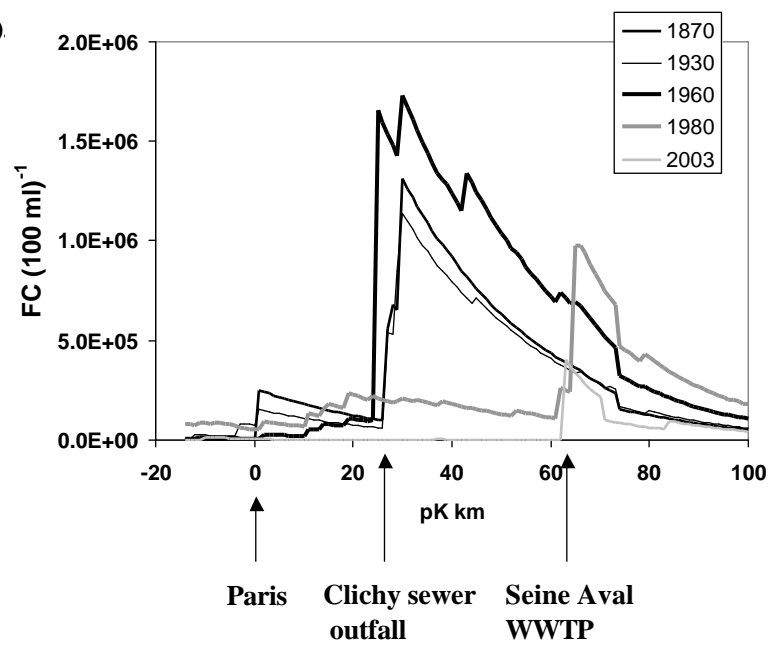

Fig. 9. (a) Historical reconstitution of the population and wastewater treatment capacity for the period 1850-2000 in the Parisian agglomeration (Billen et al., 2007); (b) Calculation of the FC concentrations by the FC-SENEQUE model along the Seine river in the Parisian area at different periods. $\mathrm{pK}$ is a kilometric unit that is set at zero at "Pont Marie" in Paris downtown and increases from upstream to downstream (negative values are thus for stations upstream Paris).

and 1960, which corresponds to a slow increase of the urban population in the watershed (Fig. 8a). From 1960, the level of faecal pollution rapidly increases due to the fast growth of urban population in the watershed (Fig. 8a). The maximum contamination is reached around 1985. Later on, the level of microbiological pollution decreases until today due to the improvement of wastewater treatment.

Figure $9 \mathrm{~b}$ shows the results of FC-SENEQUE model calculations of the longitudinal distribution of FC numbers in the Seine river in the Parisian area for key years in the period 1870-2003. In 1870, longitudinal distribution of FC shows a first increase of FC numbers when the Seine river pass through Paris, due to some direct release of untreated wastewater in Paris downtown. However, most wastewater release occurs $25 \mathrm{~km}$ downstream Paris, at Clichy, where the outfall of the main sewer was located (Fig. 1). Indeed, at 
this time, a major part of the wastewaters produced in Paris were already collected by a sewage network designed by Haussmann and Belgrand; the collected wastewaters were evacuated downstream Paris: a small part was spread on the fields at Gennevillers (west of Paris) and the main fraction released in the Seine river at Clichy without treatment. Paintings from the impressionists showing Parisians during their recreational activities (boating and bathing) in the Seine river in the area of Chatou-Bougival $(20 \mathrm{~km}$ downstream Clichy) are from this period. Using the modelling approach, we calculated levels of FC concentration around $800000 \mathrm{FC}$ $(100 \mathrm{ml})^{-1}$, i.e. a concentration 400 times higher than the level of compliance for bathing waters in the present European directive (Table 1). In 1930, the increase of faecal pollution within Paris is lower than in 1870 due to the decrease of direct release of wastewater in Paris downtown; the maximum microbiological pollution is observed downstream the wastewater release at clichy as in 1870 . The worst situation of contamination is observed for the year 1960, in agreement with the data of Fig. 9a showing that the largest gap between wastewater treatment capacity and Paris population occurs in that period, implying that the volume of wastewater released without any purification treatment in the Seine river was maximum. In 1980, the maximum faecal contamination is located downstream the release of the Achères wastewater treatment plant where most wastewater from Paris and its suburbs was treated at this period. In 2003, the maximum contamination is significantly lower than in 1980, due to the development of treatment capacity (by dry weather, the whole volume of wastewaters from Paris and suburbs is treated, direct release of untreated wastewater being restricted to some storm-flood situations) and a general improvement of the treatment efficiency in most WWTPs.

\section{Conclusions}

For the first time, a model is available to simulate microbial contamination at the scale of the whole drainage network of a large regional river basin as a result of point and diffuse sources of faecal bacteria generated by human activities. In the Seine river basin, the results of both this model and monitoring programs shows levels of faecal coliforms exceeding the present standards for bathing and other aquatic recreational activities in most large rivers sectors suitable for this use, especially in the Parisian area. Model reconstruction of the past situations shows that this was already the case since the middle of the 1950's in the large tributaries upstream from Paris, and at least since the middle of the XIXth century in the main branch of the Seine river downstream from Paris.

In the densely populated Seine basin, microbial contamination is mainly the result of urban wastewater release. The efforts carried out since 50 years for improving the treatment of this urban pollution first aimed at reducing the or- ganic matter loading, and more recently the nutrient loading of wastewater. These efforts resulted in a sensible reduction in microbiological contamination. However, up to now, no specific efforts were devoted to the treatment of faecal pollution in itself. In Europe, specific disinfection treatment of wastewater has mainly been restricted to wastewater treatment plants discharging their effluents into marine areas of high touristic values. Presently in the Seine basin, only one wastewater treatment plant is equipped for UV disinfection (the Marne-Aval plant at Noisy-le-Grand). Prospective simulations show clearly that the improvement of wastewater treatment planned for the next ten years in the scope of the european water framework directive, involving systematic tertiary treatment of nutrient, will not allow restoring in the main rivers in the Parisian area a level of faecal contamination compatible with the present and the stricter future regulations for bathing activities.

In the same time, an increasing number of local collectivities explicitly address the challenge of reopening river stretches to bathing and rowing. Recently, the city of meaux located on the Marne river $50 \mathrm{~km}$ upstream from Paris has opened a public bathing area in the river. Similar initiatives would be more difficult closer to the Parisian agglomeration where population density is much higher. However, the technical solution for reaching the required water quality level for bathing activities in these urban areas exists: it involves a further level of wastewater treatment specifically devoted to disinfection. Even if some uncertainties still exists about its long term effect on the viability of faecal bacteria (lazarova et al., 1998), UV treatment is probably one of the best technologies presently available for that purpose (Moreno et al., 1997). This technology is expensive, however: estimations are around $0.5 € \mathrm{~m}^{-3}$ (Leverenz et al., 2006), in addition to the present cost of about $1.5 € \mathrm{~m}^{-3}$ for the present level of wastewater treatment achieved in the Seine watershed.

How will the society resolve this dilemma? Economic rationality is clearly of few help here. Will the aspiration to a clean environment, materialized by the allowance of safe bathing in rivers, even if this remains an occasional and anecdotic activity without any direct economic outcome, remains high enough to lead to the generalization of more sophisticated wastewater treatment, with significant impact on the cost of water service? Will public health considerations, leading to more and more strict environmental regulations, impose them anyway? The question remains open.

Acknowledgements. This work was carried out within a large interdisciplinary program devoted to the Seine watershed: the PIREN-Seine Program coordinated by the CNRS and funded by most of the agencies involved in water management in the Seine watershed. During her participation to this study, T. GarciaArmisen has benefited from doctoral grants from the "Fonds pour la Formation à la Recherche dans l'Industrie et l'Agriculture" (FRIA) (Belgium).

Edited by: A. Ducharne 


\section{References}

AFNOR.: Qualité de l'eau. Analyses biochimiques et biologiques Analyses microbiologiques. Tome 4. Agence Française de Normalisation, Paris, France, 2001.

Barles, S.: Feeding the city: Food consumption and circulation of nitrogen, Paris, 1801-1914, Sci. Total Environ., 375, 48-58, 2007.

Billen, G., Garnier, J., and Hanset, P.: Modelling phytoplankton development in whole drainage networks: the RIVERSTRAHLER model applied to the Seine river system, Hydrobiologia, 289, 119-137, 1994.

Billen, G., Garnier, J., Ficht, A., and Cun, C.: Modelling the response of water quality in the Seine Estuary to human activity in its watershed over the last 50 years, Estuaries, 24, 977-993, 2001.

Billen, G., Garnier, J., Némery, J., Sebillo, M., Sferratore, A., Barles, S., Benoit, P., and Benoît, M.: A long-term view of nutrients transfers through the Seine river continuum, Sci. Total Environ., 375, 80-97, 2007.

Chevreuil, M., Garmouma, M., Teil, M. J., and Chestterikoff, A.: Occurrence of organochlorine (PCBs, pesticides) and herbicides (triazines, phenyluréas) in the atmosphere and in the fallout from urban and rural stations of the Paris area, Sci. Total Environ., 182, 25-37, 1996.

Collins, R. and Rutherford, K.: Modelling bacterial water quality in streams draining pastoral land, Water Res. 38, 700-712, 2004.

Diao, X. F., Li, X. Y., Gu, J. D., Shi, H. C., and Xie, Z. M.: Electron microscopic investigation of the bactericidal action of electrochemical disinfection in comparison with chlorination, ozonation and Fenton reaction, Process Biogeochemistry, 39, 1421-1426, 2004.

Duc, T. A., Vachaud, G., Bonnet, M. P., Prieur, N. Loi, V. D., and Anh, L. L.: Experimental investigation and modelling approach of the impact of urban wastewater on tropical river: a case study of the Nhue River, Hanoi, Vietnam, J. Hydrol., 334, 347-358, 2007

Edberg, S. C., Rice, E. W., Karlin, R. J., and Allen, M. J.: Escherichia coli: the best biological drinking water indicator for public health protection, J. Appl. Microbiol., 88, 106S-116S, 2000.

Garcia-Armisen, T. and Servais, P.: Respective contributions of point and non point sources of E. coli and Enterococci in a large urbanised watershed (the Seine river, France), J. Environ. Manage, 82(4), 512-518, 2007.

Garcia-Armisen, T., Prats, J., and Servais, P.: Comparison of culturable fecal coliforms and Escherichia coli enumeration in freshwaters, Can. J. Microbiol, 53(6), 798-801, 2007.

Garnier, J., Billen, G., and Coste, M.: Seasonal succession of diatoms and Chlorophyceae in the drainage network of the river Seine: Observations and modelling, Limnol. Oceanogr., 40, 750765, 1995

Garnier, J., Billen, G., Hannon, E., Fonbonne, S., Videnina, Y., and Soulie, M.: Modeling transfer and retention of nutrients in the drainage network of the Danube River, Estuar. Coast. Shelf Sci., 54, 285-308, 2002.

Garnier, J, and Billen, G.: Production vs. Respiration in river systems: an indicator of an "ecological status", Sci. Total Environ., 375, 110-124, 2007.

George, I., Petit, M., Theate, C., and Servais, P.: Distribution of col- iforms in the Seine river and estuary (France) studied by rapid enzymatic methods and plate count, Estuaries, 24(6b), 994-1002, 2001.

George, I., Crop, P., and Servais, P.: Fecal coliforms removal by wastewater treatment plants studied by plate counts and enzymatic methods, Water Res., 36, 2607-2617, 2002.

George, I., Anzil, A., and Servais, P.: Quantification of fecal coliform inputs to aquatic systems through soil leaching, Water Res., 38, 611-618, 2004.

Hamilton, W. P., Kim, M., and Thackston, E. L.: Comparison of commercially available Escherichia coli enumeration test: Implications for attaining water quality standards, Water Res., 39, 4869-4878, 2005.

Havelaar, A., Blummenthal, U. J., Strauss, M., Kay, D., and Bartram, J.: Guidelines the current position, in: Water quality: guidelines, standards and health, edited by: Fewtrell, L. and Bartram, J., World Health Organization Water Series, IWA Publishing, London (UK), 17-41, 2001.

Hoch, B., Berger, B., Kavka, G., and Herndl, G.: Influence of wastewater treatment on the microbial ecology of a large, temperate river system - the Danube River, Hydrobiologia, 321, 205-218, 1996.

Kashefipour, S. M., Lin, B., Harris, E., and Falconer, R. A.: Hydroenvironmental modelling for bathing water compliance of an estuarine basin, Water Res., 36(7), 1854-1868, 2002.

Kay, D., Bartram, J., Prüss A., Ashbolt, N., Wyer, M. D., Fleisher, J. M., Fewtrell, L., Rogers, A., and Rees, G.: Derivation of numerical values for the World Health Organization guidelines for recreational waters, Water Res. 38, 1236-1304, 2004.

Lazarova, V., Janex, M. L., Fiksdal, L., Oberg, C., Barcina, I., and Pommepuy, M.: Advances wastewater disinfection technologies : short and long term efficiency, Water Sci. Technol., 38(12), 109-121, 1998.

Lemarchand, K., Masson, L., and Brousseau, R.: Molecular biology and DNA microarray technology for microbial quality monitoring of water, Crit. Rev. Microbiol., 30, 145-172, 2004.

Leverenz, H., Darby, J., and Tchobanoglous, G.: Evaluation of disinfection units for onsite wastewater treatment systems, Center for Environmental and Water Resources Engineering, Department of Civil and Environmental Engineering. University of California, Davis. Report No. 2006-1, January 2006.

Mangerel, P.: La pollution urbaine des eaux de la région parisienne, Bull, Section de Géographie, Tome LXXX, 133-156, 1969.

Matthess, G., Pekdeger, A., and Schroeter, J.: Persistence and transport of bacteria and viruses in groundwater - A conceptual evaluation, J. Contam. Hydrol., 2, 171-188, 1988.

Menon, P., Billen, G., and Servais, P.: Mortality rates of autochthonous and fecal bacteria in natural aquatic ecosystems, Water Res., 37, 4151-4158, 2003.

Meybeck, M., de Marsily, G., and Fustec, E.: La Seine en son bassin: fonctionnement écologique d'un système fluvial anthropisé, Elsevier France, 1998.

Meybeck, M., Horowitz, A. J., and Grosbois, C.: The geochemistry of Seine River Basin particulate matter: distribution of an integrated metal pollution index, Sci. Total Environ., 328, 219-236, 2004.

Meybeck, M., Lestel, L., Bonté, P., Moilleron, R., Colin, J. L., Rousselot, O., Hervé, D., de Pontevès, C., Grosbois, C., and Thévenot, D.: Historical perspective of heavy metals contami- 
nation $(\mathrm{Cd}, \mathrm{Cr}, \mathrm{Cu}, \mathrm{Hg}, \mathrm{Pb}, \mathrm{Zn}$ ) in the Seine River basin (France) following a DPSIR approach (1950-2005), Sci. Total Environ., 375, 204-231, 2007.

Moreno, B., Goñi, F., Fernandez, O., Martínez, J. A., and Astigarraga, M.: The disinfection of wastewater by ultraviolet light, Water Sci. Technol., 35, 233-235, 1997.

MRW-DGRNE: Direction Générale des Ressources naturelles et de l'Environnement - Wallonie (Belgique), http://aquaphyc. environnement.wallonie.be/login.do, 2007.

Ottoson, J., Hansen, A., Bjorlenius, B., Norder, H., and Stenstrom, T. A.: Removal of viruses, parasitic protozoa and microbial indicators in conventional and membrane processes in a wastewater pilot plant, Water Res., 40, 1449-1457, 2006.

Ruelland, D., Billen, G., Brunstin, D., and Garnier, J.: SENEQUE: A multi-scaling GIS interface to the Riverstrahler model of the biogeochemical functioning of rivers systems, Sci. Total Environ., 375, 257-273, 2007.

Servais, P., Garnier, J., Demarteau, N., Brion, N., and Billen, G.: Supply of organic matter and bacteria to aquatic ecosystems through wastewater effluents, Water Res., 33, 3521-3531, 1999.

Servais, P., Garcia-Armisen, T., George, I., and Billen, G.: Fecal bacteria in the rivers of the Seine drainage network (France): sources, fate and modelling, Sci. Total Environ., 375, 152-167, 2007.
Strahler, A. H.: Quantitative analysis of watershed geomorphology, Geophys. Union Trans., 38, 913-920, 1957.

Tian, Y. Q., Gong, P., Radke, J. D., and Scarborough, J.: Spatial and temporal modeling of microbial contaminants on grazing farmlands, J. Environ. Qual., 31(3), 860-869, 2002.

Thévenot, D., Moilleron, R., Lestel, L., Gromaire, M. C., Rocher, V., Cambier, P., Bonté, P., Colin, J. L., de Pontevès, C., and Meybeck, M.: Critical budget of metal sources and pathways in the Seine River basin (1994-2003) for $\mathrm{Cd}, \mathrm{Cr}, \mathrm{Cu}, \mathrm{Hg}, \mathrm{Ni}, \mathrm{Pb}$ and Zn, Sci, Total Environ., 375, 180-203, 2007.

Tryland, I., Surman, S., and Berg, J. D.: Monitoring faecal contamination of the Thames estuary using semiautomated early warning system, Water Sci. Technol., 46, 25-31, 2002.

van Breemen, L. W. C. A., Ktelaars, H. A. M., Hoogenboezem, W., and Medema, G.: Storage reservoirs- A first barrier for pathogenic micro-organisms in the Netherlands, Water Sci. Technol., 37, 253-260, 1998.

WHO - World Health Organization.: Rapid assessment of sources of air, water and land pollution. WGO Offset Publication no. 62, World Health Organisation, Geneva, Switzerland, 1982. 